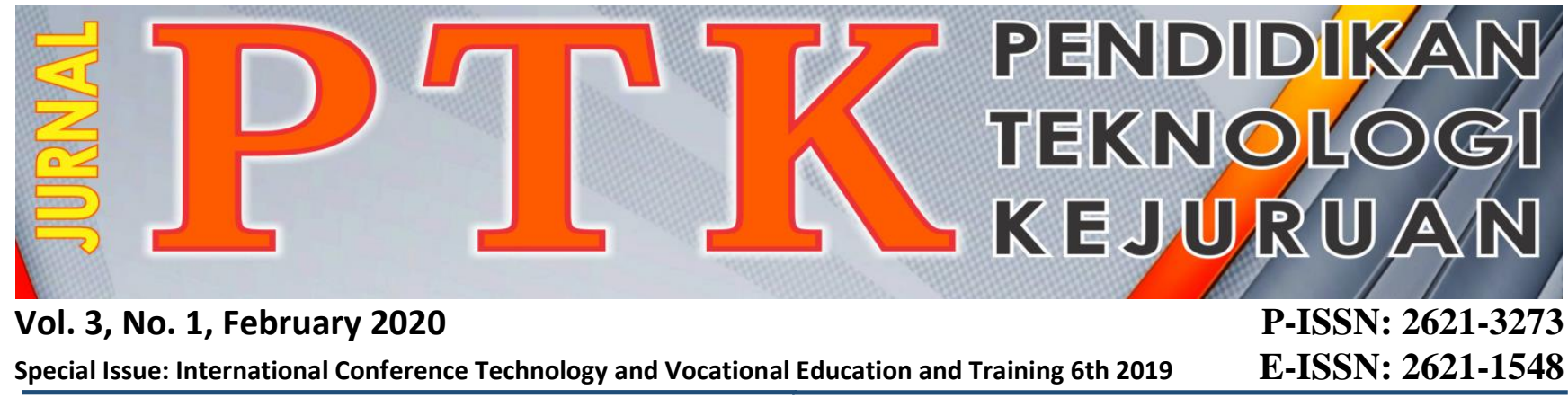

\title{
A NEEDS ANALYSIS FOR THE DEVELOPMENT OF E-MODULES PROJECT-BASED LEARNING
}

\author{
Ismi Rahayu ${ }^{1 *}$ and Sukardi ${ }^{2}$ \\ ${ }^{1 *}$ Vocational Technology Education, Enginering Faculty, Universitas Negeri Padang \\ ${ }^{2}$ Faculty of Engineering, Universitas Negeri Padang \\ *Corresponding author, e-mail: ismirahayu32@gmail.com
}

\begin{abstract}
This research aims to describe the results of the needs analysis for the development of electronic module project- based learning. This research was a qualitative descriptive study by using survey methods in identifying the needs of students and teachers in learning assessment. In this research, needs analysis refers to the achievement of student learning outcomes, problems faced by students, and the media needed in the learning assessment process. This research used observation and interview methods in collecting the data. Observations and interviews were done for the students of grade $X$ of computers and basic networks subject at SMKN 5 Padang. The results showed that: 1) completeness of student learning 2) Interactive learning media needed on computer and basic networks subject. The results of this research concluded that students need interactive learning media in learning activities. Thus, this research is used in designing electronic module project based learning.
\end{abstract}

Keywords: E-Module, Project Based Learning

Copyright @ 2020 JPTK. All rights reserved

\section{INTRODUCTION}

Solomon mentions the pattern of theory development from the bottom up (the pattern of bottom-up theory development). Learning media that discusses physical communication devices consisting of hardware and software is a small part of learning technology that must be created, used, and managed (evaluated) for learning needs with a view to achieving effectiveness and efficiency for the learning process [1].

The advances in technology and information in the 21 st century continue to develop that change human patterns bring changes to education. In the 21 st century of education, the skills needed by students to be able to compete globally are critical thinking skills, communication skills, innovation, problem-solving through negotiation and collaboration and an entrepreneurial spirit as well as the ability to access, and analyze information [2].

E-modules is a way of organizing subject matter that pays attention to the function of education. By using E-modules learning is expected to be able to bring students to the competencies expected. The Emodules contains sequencing which refers to making the order of presentation of learning material and synthesizing which refers to an effort to show students the relationship of facts, concepts, procedures and principles contained in the learning material. There are five categories of capabilities that can be learned by students: (1) verbal information, (2) intellectual skills, (3) cognitive strategies, (4) attitudes and (5) motor skills [3].

E-modules manages subject matter that pays attention to educational functions. E-modules project-based learning is expected to bring students to the expected learning competencies. E-Modules contains a sequence that refers to making a sequence of presentation of learning material and synthesizing which refers to an effort to show students the relationship of facts, concepts, procedures and principles contained in the learning material. There are five categories of abilities that students can learn: (1) verbal information, (2) intellectual skills, (3) cognitive strategies, (4) attitudes and (5) motor skills [4]. 
E-modules project-based learning media that teach in electronic form. Therefore, students can use the E-modules as a study guide that provides guidelines and learning methods so students can learn on their own, so through this e-modules, it will make students more independent in learning and can help participants who must be controlled by these students. Before making this e-modules or electronic modules, the birth of the print modules first facilitated students in teaching and learning activities, but in the use of this print, the learning module became unattractive because the print module could not open interactive messages, like showing a visual video image.

Table 1. The results of practicum for students of grade $\mathrm{X}$ of computer and network engineering on the computer and basic networks subject.

\section{Class}

Succeed

Failed
Class $\mathrm{x}$ computer and basic networks
22 8
The results of the score of computer practice and basic network using print modules reached 22 students were complete and 8 students were not yet completed. Thus, the use of printed modules needs to be made new innovations by using e-modules to increase the grade of low students. One very important change is applied in learning media.

The changes in learning media can be done by creating new media or developing existing media. The development of instructional media is considered important because of students' needs for learning media that support independent learning so that they are no longer dependent on the use of practical tools and materials that can only be used in the laboratory. The development of learning media must be able to present practical tools and materials so that learning can be done independently outside the laboratory, which is then expected to minimize failures in practice and improve student learning outcomes. The development of instructional media in minimizing this problem can utilize E-modules project-based learning. E-modules is an electronic module that combines tutorials, visual images that make it easy for students to do lab work in a laboratory [5].

The changes in learning media can be done by creating new media or developing existing media. The development of instructional media is considered important because of students' needs for learning media that support independent learning so that they are no longer dependent on the use of practical tools and materials that can only be used in the laboratory. The development of learning media must be able to present practical tools and materials so that learning can be done independently outside the laboratory, which is then expected to minimize failures in practice and improve student learning outcomes.

The development of instructional media in minimizing this problem can utilize E-modules project-based learning. E-modules is an electronic module that combines tutorials, visual images that make it easy for students to do lab work in a laboratory [6]. The e-module uses an Android studio application that displays learning material in digital form so students can carry out their learning independently using a smartphone. Electronic modules make it easy for students to learn because students do not need to repeat and open printed books [7]. Many types of research have been done in the development of project-based learning media that results in changes that are good for the process and learning outcomes [9]-[11]. The advantages of this project-based learning will be developed into learning media. Thus, the researcher is interested to conduct research on e-module project-based learning on the computer and basic networks subject.

\section{METHODOLOGY}

Because research was the initial stage of research and development (R\&D), this research was limited to analyzing needs by making observations. This research involved the students of grade $\mathrm{X}$ majoring in computer and network engineering at SMKN 5 Padang. There were 30 students who participated in giving opinions about what they needed in basic computer and network learning activities. In addition, there were 2 basic computer and network teachers.

This research used a descriptive research method. Qualitative research methods are research methods based on the philosophy of positivism, which are used to examine populations or specific samples; research data are collected by using research instruments, quantitative or statistical data analysis, with the aim of testing the established hypotheses [12]. The data were collected through observation and interview techniques with instruments in the form of a questionnaire. The questionnaire was used to find out students' opinions related to the needs of the learning media developed. The data obtained from the questionnaire were analyzed and then summarized in a table.

The data obtained from the use of questionnaire analysis of the needs of lecturers and student needs. 
The data obtained were processed in four stages: 1) collecting data from questionnaire distribution. 2) tabulating data to see the class, nature, type, and frequency of data. 3) Data tabulation aims to facilitate reading, categorizing, and analyzing data. 4) making the interpretation of the problem analyst's results and the researcher's questions, so they can draw conclusions.

\section{RESULTS AND DISCUSSION}

A needs analysis for the development of emodules project-based learning on the computer and basic networks subject obtained through observation and interviews. Monitoring was carried out by 30 the students of grade $\mathrm{X}$ majoring in computer and basic networks subject and 2 computer teachers and basic networks in the July-December 2019 semester. The monitoring of the research results obtained in table 2 .

Table 2. The Results of analysis of teacher needs regarding electronic learning media, computer modules and basic networks

\begin{tabular}{l}
\hline Qu \\
\hline 1 Question Analysis \\
used conventional methods \\
$40 \%$ of teachers answered that the \\
2 conventional learning process was not \\
suitable for increasing student grades \\
$50 \%$ of teachers answered that the \\
3 conventional learning process caused a lack \\
of variation in learning \\
$100 \%$ of teacher answered that learning \\
$4 \begin{array}{l}\text { activities really need interactive learning } \\
\text { media, so learning was not only focused on }\end{array}$ \\
the teacher \\
$50 \%$ of teachers answered that the learning \\
5 process did not involve the student in the \\
presence of interactive learning media \\
$100 \%$ of teachers answered that the learning \\
process still used print media
\end{tabular}

Identification of Problems

The learning process was still conventional towards the delivery of learning material

changing learning methods to improve student grades

variation of learning needs to be done

variation of learning needs to be done

\section{Conclusion}

Learning activities using the conventional method

Replace the learning method

Learning variations need to be done

Learning variations that enhance student grades

using interactive media in learning Make interactive media activities in learning

involving interactive media in learning activities

Requires interactive learning media
Based on the results of the analysis of learning resources conducted, the students have not used electronic modules in the learning process. The development of electronic computer modules and basic networks were needed, especially in the field of computer and network engineering. The use of electronic modules was very helpful for students in practical activities in the laboratory because it was completed with animation, images and tutorial.

The development of electronic modules projectbased learning was carried out by the process of collecting data such as curriculums, computer materials and basic networks, the number of students, and the list of student grades. In learning, it is expected to have the skills and creativity that make learning effective, for example by selecting models, media and learning instruments [13]. Therefore, observations were made on students about the problems and expectations of media assessment of basic computer and network lessons needed. The results of research on students in the form of data obtained were shown in table 3 . 
Table 3. The Results of analysis of students' needs for assessment media on basic graphic design

\begin{tabular}{cl}
\hline No. & Question Analysis \\
\hline 1 & $50 \%$ of students answered that learning still used conventional methods \\
2 & $50 \%$ of students answered that print media was still too difficult to use in practical work \\
3 & $60 \%$ of students answered that it took a long time to reopen the page while practising \\
4 & $50 \%$ of students were interested in using interactive media in learning to use smartphone \\
& technology \\
5 & $60 \%$ of students were interested in using interactive media as a practical learning media \\
6 & $50 \%$ of students answered interactive media more efficiently in learning activities
\end{tabular}

The results of the analysis of student needs showed that $70 \%$ of the students had difficulty doing a practicum in computer and basic network lessons. Therefore, $90 \%$ of students have and are able to use smartphone technology, and that can be used in the learning process. Utilization of information and communication technology could be done in the learning process as a form of evaluating student progress in learning. The use of electronic modules in learning is important because along with technological developments will affect the development of practicum learning processes [14].

The product developed was a project-based learning electronic module. Electronic module with $\mathrm{EPuB}$ format that could be accessed via a smartphone with an Android system. Project-based electronic module development was carried out through 5 phases: defining, designing, developing, implementing and evaluating.

The first stage was defining. Through this stage, a needs analysis was obtained in the development of E-Module based project learning. The software needed in the development of the electronic module process is Android Studio The hardware required in this research was the Windows 10 operating system, and the minimum hardware specifications that can be used are the 64-bit processor and Intel® processor operating systems with support for Intel ${ }^{\circledR}$ VT -x, Intel® EM64T (Intel® 64), and Execute Disable (XD) Bit Function, 3GB RAM, with 2GB of available disk space.

The use of this media in the form of electronic modules was by using technology such as smartphones and could be accessed online and offline. The use of online and offline media connected the students and the teachers in learning. Learning using interactive media is considered as part of the learning process that provides ongoing feedback for students and educational institutions [15]. This was needed to develop interactive electronic assessments that can be accessed online using smartphones for basic computer and network lessons based on needs analysis. This needs analysis showed $100 \%$ of the teacher needs in improving the quality of learning media and $90 \%$ of student needs for media assessment are mobile, interactive and support learning activities.

\section{IV.CONCLUSION}

This research aims to describe the results of the needs analysis in the process of developing electronic modules in computer and basic networks subject. Based on the results and discussion of this research, it showed that the development of electronic e-modules was needed. The needs analysis showed that there were $100 \%$ of teachers who needed to improve the quality of assessment and learning assessment media. In addition, $90 \%$ of the students needed an assessment media that was interactive, mobile, and utilizes technology so that they could complete projects without having to reopen printed books. Therefore,

Based on preliminary studies and the results of observations and interviews, the expected objectives of this research were; 1) there were students who have not yet reached the KKM score because the students have not been maximized in carrying out practicum 2) In practicum activities there were no electronic modules that could make the students achieve the KKM 3) Interactive media needed to be improved and developed in learning computer and basic networking.

\section{REFERENCES}

[1] Solomon. Metode Penelitian Kuantitatif Kualitatif dan R\&D. Bandung: Alfabeta. 2012.

[2] Siti Zubaidah. "Keterampilan Abad Ke-21: Keterampilan yang Diajarkan Melalui Pembelajaran". Seminar Nasional Pendidikan, 2(2), 1-17. 2016.

[3] Sadiman, A.S, dkk. Media Pendidikan: Pengertian, Pengembangan dan Pemanfaatannya. Jakarta: Pustekkom Dikbud dan PT Raja Grafindo Persada. 2006.

[4] Safaat H, Nazaruddin. Pemrograman Aplikasi Smartphone dan Tablet PC berbasis Android (Bandung: Informatika) p 1. 2012. 
[5] Adi wiyana, Kadek. Pengembangan E-Modul Berbasis Project Based Learning Pada Mata Pelajaran Pemrograman Web Kelas X di SMK Negeri 3 Singaraja. 2016.

[6] Daryanto. Menyusun Modul. Yogyakarta: Geva Media. 2013.

[7] Direktorat Tenaga Kependidikan. Penulisan Modul. (Online). 2008.

[8] Nurdyansyah \& Eni Fariyarul. Inovasi Model Pembelajaran. Sidoarjo: Nizamia Learning Center. 2016.

[9] Milentijevic, I., Ciric, V., \& Vojinovic, O. Version Control in Project- Based Learning. Computers and Education. Volume: 50, 1331-1338. 2008.

[10] Rusman. Belajar dan Pembelajaran Berbasis Komputer. Bandung: Alfabeta Bandung. 2012.

[11] Yudhi Munardi. Media Pembelajaran Sebuah Pendekatan Baru. Jakarta : Ciputat Mega Mall. 2013.

[12] Richey, R. C., \& Klein, J. Design and Development Research: Methods, Strategies, and Issues. Article. Mahwah, NJ: Lawrence Erlbaum Associates, Publishers. 2007.

[13] Sorensen E. Implementation and student perceptions of e-assessment in a Chemical Engineering Module European Journal of Engineering Education (vol 38) chapter $2 \mathrm{pp}$ 172-185. 2013.

[14] S. Syahril, N. Jalinus, R. A. Nabawi, and Y. Arbi, "The Create Skills of Vocational Students to Design a Product: Comparison Project Based Learning Versus Cooperative Learning-Project Based Learning," Adv. Soc. Sci. Educ. Humanit. Res., vol. 299, no. 5th UPI International Conference on Technical and Vocational Education and Training (ICTVET 2018) The, pp. 316-320, 2019. 